\title{
After the Global Fund: who can sustain the HIV/AIDS response in Peru and how?
}

\author{
Ana B. Amaya, $\mathrm{MPH}^{1,2}$ \\ ana.amaya@1shtm.ac.uk \\ Carlos F. Caceres, $\mathrm{MD}, \mathrm{PhD}^{2}$ \\ carlos.caceres@upch.pe
}

Neil Spicer, $\mathrm{PhD}^{1}$

neil.spicer@1shtm.ac.uk

Dina Balabanova, $\mathrm{PhD}^{1}$

dina.balabanova@1shtm.ac.uk

-Department of Global Health and Development. London School of Hygiene and Tropical Medicine. London, United Kingdom

-Institute for Health, Sexuality and Human Development. Universidad Peruana Cayetano Heredia. Lima, Peru.

Keywords: Global Fund, sustainability, HIV, governance, actors 


\section{Corresponding author:}

Ana B. Amaya MPH

Ana.amaya@1shtm.ac.uk

London School of Hygiene and Tropical Medicine

15-17 Tavistock PL,

London WC1H 9SH,

UK 


\title{
After the Global Fund: who can sustain the HIV/AIDS response in Peru and how?
}

\begin{abstract}
Peru has received around $\$ 70$ million for HIV/AIDS from Global Fund to fight AIDS, Tuberculosis and Malaria (Global Fund). Recent economic growth resulted in grant ineligibility, enabling greater government funding; yet doubts remain concerning programme continuity. This study examines the transition from Global Fund support to increasing national HIV/AIDS funding in Peru (2004-2012) by analysing actor roles, motivations, and effects on policies, identifying recommendations to inform decision-makers on priority areas.

A conceptual framework, which informed data collection was developed. Thirty-five in-depth interviews were conducted from October to December 2011 in Lima, Peru, among key stakeholders involved in HIV/AIDS work.
\end{abstract}

Findings show that Global Fund involvement led to important breakthroughs in the HIV/AIDS response, primarily concerning treatment access, focus on vulnerable populations and development of a coordination body. Nevertheless, reliance on Global Fund financing for prevention activities via non-governmental organisations, compounded by lack of government direction and weak regional governance, diluted power and caused role uncertainty. Strengthening government and regional capacity and fostering accountability mechanisms will facilitate an effective transition to government-led financing. Only then can achievements gained from the Global Fund presence be maintained, providing lessons for countries seeking to sustain programmes following donor exit. 


\section{Introduction}

A large number of low and middle-income countries currently receive considerable amounts of aid to support their HIV/AIDS programmes, thus making the question of how to sustain these programmes central to the international development agenda (UNAIDS, 2013). There are many definitions for sustainability, usually associated with words such as 'continuity' (Scheirer, 2005; UNICEF, 1992), 'maintenance' (LaPelle, Zapka \& Ockene, 2006; Gruen et al, 2008; Shediac-Rizkallah \& Bone, 1998) or 'incorporation/implementation' (Bracht et al., 1994; Pluye, Potvin \& Denis, 2004; Stefanini \& Ruck, 1992). In this paper, sustainability is defined as the capability of a government to manage health programmes long-term without depending on the intervention of external bodies for technical or financial support within a given social, political and economic environment.

Until 2010, Peru financed a large portion of HIV/AIDS programmes through external assistance. From 2005 to 2010, 48.6\% of the funding for HIV/AIDS was provided by international organisations; $36.5 \%$ was financed by the government; and $14.9 \%$ by the private sector (Navarro de Acosta, 2011). Bilateral donors such as USA Agency for International Development (USAID), Department for International Development (DFID), German Society for International Development (GiZ) and international organisations such as Doctors without Borders and UNAIDS played a key role in providing aid the past (Ministerio de Salud del Peru, 2006). However, since its entry in 2004, the Global Fund to fight AIDS, Tuberculosis and Malaria (Global Fund) has been the most important financial donor for HIV/AIDS (Cabrera, 2010),, providing over US\$70 million in the 2004-2012 period via four approved rounds (Table 1) for the implementation of HIV/AIDS projects, primarily supporting prevention activities (Global Fund, 2012). The percentage of Global Fund funding as a share of total HIV/AIDS expenditure fluctuated in the 2005-2010 period, the lowest point reached 
in 2005 with an $11 \%$ contribution and the highest in 2008 with $28 \%$ of total HIV funding

(Ministerio de Salud del Peru, 2012).

Table 1 HIV/AIDS Global Fund-approved grants

\begin{tabular}{|c|c|c|c|c|}
\hline Round & Grant title & $\begin{array}{c}\text { Total } \\
\text { approved }\end{array}$ & $\begin{array}{l}\text { Principal } \\
\text { recipient }\end{array}$ & Main activities \\
\hline 2 & $\begin{array}{l}\text { "Strengthening prevention } \\
\text { and control of AIDS in } \\
\text { Peru". (2004-2008) }\end{array}$ & $\$ 21,347,134$ & CARE Peru & $\begin{array}{l}\text { - Increasing access to diagnosis, } \\
\text { treatment and prevention of } \\
\text { vertical transmission } \\
\text { - Prevention actions such as } \\
\text { prevention of mother to child } \\
\text { transmission (PMTCT), sex } \\
\text { workers and men who have sex } \\
\text { with men (MSM) } \\
\text { - Care among people living with } \\
\text { HIV/AIDS (PLHA) } \\
\text {-Prevention activities such as } \\
\text { behavioural interventions and } \\
\text { condom distribution programmes } \\
\text {-Strengthening civil society and } \\
\text { reducing stigma }\end{array}$ \\
\hline 5 & $\begin{array}{l}\text { “Closing gaps to achieve } \\
\text { Millennium Development } \\
\text { Goals for HIV/AIDS in } \\
\text { Peru”. (2006-2010) }\end{array}$ & $\$ 11,702,911$ & CARE Peru & $\begin{array}{l}\text {-Strengthen objectives set in } \\
\text { round two with exception of ART } \\
\text { treatment which by } 2007 \text { was } \\
\text { funded by the government }\end{array}$ \\
\hline 6 & $\begin{array}{l}\text { "National Multi-sectoral } \\
\text { plans: Integrating } \\
\text { resources for the Fight } \\
\text { against HIVIAIDS in Peru”. } \\
(2007-2011) .\end{array}$ & $\$ 31,827,512$ & CARE Peru & $\begin{array}{l}\text {-Strengthen objectives set in } \\
\text { round five } \\
\text {-Proposal was centred around } \\
\text { developing decentralised } \\
\text { activities at the national-level, } \\
\text { identifying three macro-regions: } \\
\text { North, South-Central and Eastern }\end{array}$ \\
\hline 10 & \begin{tabular}{|l|} 
"Building social capital to \\
prevent HIV and improve \\
access to comprehensive \\
healthcare without \\
transphobia or homophobia \\
for the transsexual, \\
gay/MSM population in \\
Peru”. (2012-2013).
\end{tabular} & $\begin{array}{c}\text { \$4,344,113 } \\
\text { (phase I) } \\
\text { Phase II to be } \\
\text { submitted in } \\
\text { August } 2013 \\
\end{array}$ & \begin{tabular}{|c|} 
Instituto \\
Peruano de \\
Paternidad \\
Responsable \\
(note that \\
Phase Il will \\
be \\
administered \\
by \\
PARSALUD \\
as PR)
\end{tabular} & $\begin{array}{l}\text {-Strengthening capacity among } \\
\text { key populations of MSM and } \\
\text { transgendered } \\
\text { - Training community agents for } \\
\text { prevention and care } \\
\text { - Sensitising law enforcement } \\
\text { officials }\end{array}$ \\
\hline & Tot & $9,221,670$ & & \\
\hline
\end{tabular}


Country recipients of Global Fund assistance are expected to create national structures called Country Coordination Mechanisms (CCMs) to identify priorities, develop and submit proposals according to the specific priorities and harmonise disease-specific programmes with national policies and programmes. They also act as overseers of grant implementation and liaise on emerging issues with the Global Fund (Global Fund, 2011b). Peru established such a body of country actors in 2004, namely the National Multisectoral Coordinating Centre in Health (CONAMUSA: Coordinadora Nacional Multisectorial de Salud), with representation of different government sectors, civil society and international stakeholders. The committee has sought to decentralise some of its functions in line with the country administrative decentralisation process, and created Regional Multisectoral Coordinating Agencies for Health (COREMUSAs) (Buffardi, Cabello \& Garcia, 2011). However, these regional coordination centres have yet to be formally registered and lack access to resources (Caceres et al., 2009).

The context of external assistance in Peru has changed. In 2011 the HIV/AIDS programme was included into a national results-based budget, a strategy which seeks to focus government resources on key populations and achieve impact (Cabrera, 2010). Indeed between 2011 and 2012, government investment in HIV/AIDS and tuberculosis activities grew from $0.2 \%$ of the total budget to almost $0.4 \%$ (Ministerio de Economia y Finanzas del Peru, 2012). Furthermore, Peru became an upper-middle-income country due to strong economic growth in the past years (World Bank, 2013a). However, inequality levels remain high, with the World Bank (2013b) reporting a GINI index in 2010 of 48.1. Additionally, due to this upper-middle-income status, Peru can now only apply for smaller Global Fund grants focused on key populations, as is the case for round 10 (Global Fund, 2012a). This is due to Global Fund eligibility criteria that rates countries according to their disease burden, political 
commitment, effectiveness of their CCM and the poverty situation in the country (Global Fund, 2011a).

However there is a lack of clarity about the continuity of specific dimensions of the national HIV/AIDS response (particularly if they have been successful and are still deemed necessary) and the roles and responsibilities of different country actors. There have been justifiable concerns about the sustainability of HIV/AIDS programmes and achievements, as well as other health programmes that were created to address genuine need. In some cases, donor interest may be prematurely discontinued (Gruen et al., 2008). Discontinuation of programmes not only leaves unmet needs, it can be wasteful of human, monetary and technical investments and can decrease community trust and support for future programmes (Shediac-Tizkallah \& Bone, 1998). Moreover, actor incentives and asymmetries in access to knowledge about the context in which projects are being implemented have been found to hinder sustainable development outcomes, following development assistance (Ostrom, Gibson, Shivakumar \& Andersson, 2001).

While the end goal of sustainability is relevant to many countries, the economic development of a particular country frequently determines its ability to continue to fund activities once a donor leaves (Lu, Michaud, Khan \& Murray, 2006; Ooms, 2006). Moreover, sustainability also requires the political commitment to continue to prioritise these programmes (Atun et al, 2005; Schell, et al, 2013). A clear example is Russia, now an upper-middle-income country (World Bank, 2013), and no longer eligible for Global Fund grants, where after the end of Global Fund grants, the government reneged its commitment to continue funding for HIV prevention activities among drug users due to pressure from the church and political lobbing (Twigg, 2007). Due to this, the Global Fund convened a meeting to discuss the case and decided to provide funding for a further two years (Global Fund, 2009; International AIDS Society, 2009). In this case, disruption is not due to scarce resources but resistance to 
internationally accepted best practices and state policies excluding groups that are not seen as socially deserving.

Existing evidence shows that programmes that are primarily donor-driven jeopardise the sustainability of country health programmes since they often ignore the original priorities of a country and disrupt investment in training health workers to continue the projects (Dickinson, 2008; Lele, Saran, Govindaraj \& Konstantopoulos, 2004), creating aid dependence in the long term.

This paper seeks to enrich current knowledge on these important issues by means of a historical case study designed to capture the transition from Global Fund entry in 2004 through increased financing of HIV/AIDS programmes by the government, until 2012. This type of study is particularly relevant in the current context of fiscal constraints, where donors are targeting funding to countries that need it the most, as well as the increasing number of countries graduating from aid as their income increases (Glassman, Duran \& Sumner, 2012). Thus, the 2012-2016 Global Fund funding model focuses on investing in areas with high potential for impact and increasing the sustainability of funded programs (Global Fund, 2011c). The paper examines the enabling and limiting factors during this process, with a focus on actor motivation and influence on programme implementation. Furthermore, this study is based on the proposition that the Global Fund investment in the HIV response in Peru has developed the necessary structures and processes for a coordinated and sustained response from all actors towards the continuity of successful policies and interventions led by the government. The recommendations derived from this study seek to inform countries becoming less dependent on external assistance but facing similar constraints, and to contribute to the global policy debate on the effect of donor assistance on national health policies. 


\section{Framework}

This study employed a historical case study approach - it involved policy policy analysis and was guided by a conceptual framework. A number of frameworks have sought to conceptualise sustainability of policy and programmes in the health sector (Gruen et al., 2008; LaPelle, Zapka \& Ockene, 2006; Olsen, 2010; Torpey, Mwenda, Thompson, Wamuwi \& van Damme, 2010). These vary in terms of the aspects of sustainability they refer to and the explanatory factors considered regarding how countries cope after funding ends. LaPelle et al. (2006) provide a framework based on two strategies which are based on redefining the scope of services and creatively using limited resources; yet their focus on finding funding and creating demand for services is already defined in our case. Torpey and colleagues' (2010) framework is useful in differentiating between technical, programmatic, social and financial sustainability, though they concentrate on service delivery, rather than explaining the policies that made the outcome possible, which is the objective of the present study. Gruen and colleagues' (2008) framework represents health programme functions as a complex system that depends on the interactions between health concerns, programme components and the programme drivers, within a sociocultural, political and geographical context; which are also shaped by health system characteristics and resources available. Still, this framework does not capture comparisons over time periods or inputs that make the relationships happen. Olsen's (2010) framework focuses on health services in low income countries, based on: contextual factors, activity profile and organisational capacity. Again, the model does not support the study of complex processes and the interactions between different components. 
For this study, a hybrid model (Figure 1) was developed drawing on the strengths of Olsen's (1998) and Gruen and colleagues' framework (2008).

Figure 1 Framework based on Gruen et al (2008) and Olsen's (1998) sustainability frameworks1,2

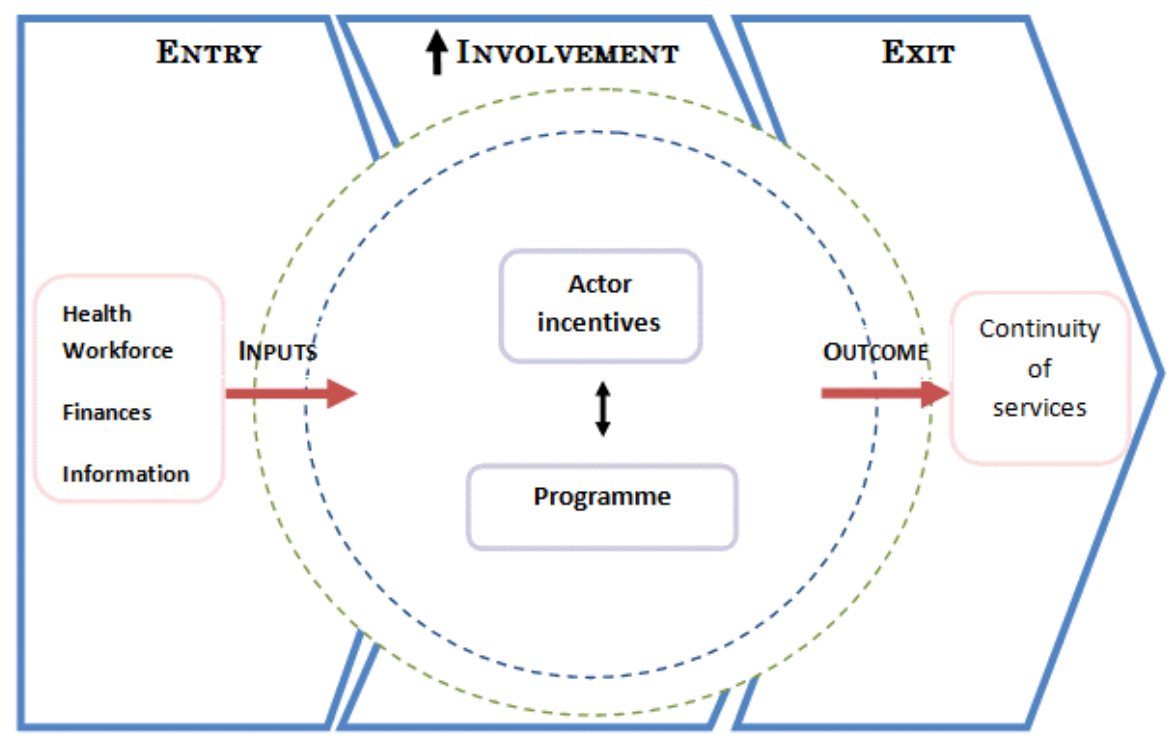

External Environment

Task Environment

This framework represents an open system (a system that functions by constantly interacting with its surroundings) where organisations are exposed to the social, political and economic context in the country and must adapt to it in order to function ('external environment'). This external environment is composed by those factors that affect health but are not part of the health system, including government policies, social indicators such as inequality and employment levels; as well as the economic context that in the case of Peru is a favourable

\footnotetext{
${ }^{1}$ Olsen, I. (1998). Sustainability of health care: a framework for analysis. Health Policy and Planning, 13, $287-295$.

2 Gruen, R. L., Elliot, J. H., Nolan, M. L., Lawton, P. D., Parkhill, A., McLaren, C. J., Lavis, J. N. (2008). Sustainability science: an integrated approach for health-programme planning. The Lancet, 372, 1579-89.
} 
economic environment. Moreover, this framework looks at inputs (resources invested in programmes), actor incentives, programme response and the outcome, which is a continuity of activities. The inputs such as the country capacity, finances and data available on the disease burden are essential for an appropriate response. These resources shape how programmes will be implemented and which actors will plan and implement these programmes. The actors and the programme are both found within the 'task environment', which are those factors related to health and HIV/AIDS that have an effect on how actors behave in the programme.

The programme component includes the HIV/AIDS policies (including financing arrangements) and activities in place, and the perceived effectiveness of the response. If actions are to take place and be sustained, it is critical to consider the incentives and roles of the key actors including their leadership, mutual relationships and coordination of tasks, which have a direct impact on the programme. As the figure demonstrates, this relationship is bidirectional given that actors develop programmes according to the inputs and their own priorities of what is needed, but at the same time, the programme also has an effect on actor incentives, according to the weaknesses and strengths identified when implementing the programme.

All of this has an effect on the outcome of interest, which is the continuity of activities. The framework allows these elements to be captured over time, with key phases being: 1)Global Fund entry in Peru in 2004, 2)full-blown involvement, and 3)preparation for exit in 2012. Interpreting the outcomes, programmes and actor roles as they are now, requires an understanding of the history of current policies and relationships.

This framework was used to identify themes and relationships emerging from the data. Given the central role of actors in the implementation of the programme, this paper specifically 
focused on the actor incentives and programme response components as key explanatory factors for ensuring policy and programme sustainability.

\section{Methods}

A historical case study approach was adopted to analysing the period of 2004 to 2012 , focusing on how the behaviour of different actors enabled or hampered the move towards sustainability of national financing for HIV/AIDS programmes. The case study involved conducting 35 in-depth interviews in Lima, Peru (October-December 2011), guided by the framework among four types of national and international stakeholders currently or formerly responsible for HIV work (Table 2). The in-depth interviews allowed us to explore predefined themes while giving the respondent freedom to bring in new perspectives and make linkages between events and outcomes (Yin, 2003). Moreover, interviews questions were adapted if necessary according to the respondent's expertise and decision-level in order to obtain responses that were compared to other similar respondents. Respondents were selected on the basis of their involvement in HIV work or expertise during the period of study; as well as direct or indirect participation in Global Fund projects. "Chain sampling", a method which involved asking stakeholders to nominate other potential respondents (Mays \& Pope, 2000), was also used to ensure diverse representation of relevant actors within the study.

This was complemented by a documentary review, which entailed a review of grey literature, policy documents, peer-reviewed articles, and national laws and local news articles in Spanish and English on issues surrounding the HIV/AIDS programme in the country, the results-based budgeting strategy and the Global Fund proposals, published in the 2000-2012 period. Key terms included "HIV”, “AIDS”, “financing”, "sustainability”, “coordination”, 
"aid", "decentralisation", “Global Fund" and "Peru”. Databases searched included

MEDLINE/Pubmed, LILACS, Web of Science, Global Health, EMBASE and Google

Scholar. This data provided the contextual basis for the study and informed the interpretation of main emerging themes, enabling triangulation.

Ethical approval was obtained from the Universidad Peruana Cayetano Heredia (approved the 11 October 2011, reference number 058954) and the London School of Hygiene and Tropical Medicine (approved the 7 September 2011, reference number 6022). Participants were provided with information, guaranteed confidentiality and asked to sign a consent form.

Table 2. Respondent characteristics

\begin{tabular}{|c|c|c|c|}
\hline Sector & $\begin{array}{l}\text { Number of } \\
\text { interviews }\end{array}$ & Institutions & Positions \\
\hline Government & 10 & $\begin{array}{l}\text { Ministries of health; } \\
\text { education; women \& social } \\
\text { development; finance \& } \\
\text { economics; foreign affairs; } \\
\text { justice. CONAMUSA and } \\
\text { COREMUSA leaders. } \\
\text { Regional health leaders. }\end{array}$ & $\begin{array}{l}\text {-High-level \& middle-level } \\
\text { management at the central level. } \\
\text { - Regional and local-level leaders. } \\
\text { - Coordinating mechanisms } \\
\text { leaders. }\end{array}$ \\
\hline \begin{tabular}{|l|} 
International \\
organisations
\end{tabular} & 7 & \begin{tabular}{|l} 
Bilateral (3) \\
Multilateral (4)
\end{tabular} & $\begin{array}{l}\text {-High-level \& middle-level } \\
\text { management. } \\
\text { - Program officers. }\end{array}$ \\
\hline $\begin{array}{l}\text { NGOs and } \\
\text { CSOs }\end{array}$ & 14 & $\begin{array}{l}\text { National-level NGOs \& CSOs } \\
(9) \\
\text { Regional-level NGOs \& } \\
\text { CSOs (5) }\end{array}$ & $\begin{array}{l}\text {-CSO \& NGO leaders. } \\
\text { - Project implementers. } \\
\text {-Coordinating mechanism } \\
\text { members }\end{array}$ \\
\hline Academia & 4 & Three universities & $\begin{array}{l}\text {-Heads of research units } \\
\text { - University professors }\end{array}$ \\
\hline ITOTAL & 35 & & \\
\hline
\end{tabular}

Following data collection, the documentary data and the interviews were analysed using the original framework mentioned in the previous section. Thematic analysis (Green \& 
Thorogood, 2004) was used to examine the interviews and the qualitative software NVivo (version 10), provided a space to organise and code emerging themes. Specific attention was paid to interpreting the actors' roles, the meaning of the relationships and their impact on programmes and their sustainability. These interpretations were triangulated with the documentary review and analytical field notes, to arrive at policy recommendations.

\section{Findings}

A number of themes emerged from our interviews as central to explaining the process of an expanded role of national actors and moving towards sustainable HIV response. These relate first, to actor incentives (mechanisms for joint work and the power and position of civil society); second, to the nature of programme implementation (government prioritisation of the HIV response, the effect of Global Fund on policy and practice; and the impact of country decentralisation as a key contextual factor affecting sustainability); and finally, the perception of the future positioning of these actors in programmes sustained at the national-level. Table 3 provides an overview of the main actor roles. 
Table 3 Main actor roles

\begin{tabular}{|c|c|c|c|c|c|c|}
\hline • & $\begin{array}{c}\text { Main responsibilities in HIV/AIDS policies } \\
\text { and programmes }\end{array}$ & $\begin{array}{l}\text { Involvement } \\
\text { with other } \\
\text { actors }\end{array}$ & $\begin{array}{l}\text { Level of } \\
\text { participation in } \\
\text { CONAMUSA }\end{array}$ & $\begin{array}{c}\text { Received } \\
\text { money from } \\
\text { the Global } \\
\text { Fund }\end{array}$ & $\begin{array}{c}\text { Role } \\
\text { change } \\
\text { after Global } \\
\text { Fund entry }\end{array}$ & $\begin{array}{l}\text { Relationship with } \\
\text { Global Fund }\end{array}$ \\
\hline \multicolumn{7}{|l|}{ Government } \\
\hline STI \& HIV strategy office & $\begin{array}{l}\text { - Leading and coordinating the HIV/AIDS } \\
\text { response } \\
\text {-Development of policies and plans. }\end{array}$ & All sectors & High & $\begin{array}{c}\text { Yes } \\
\text { (indirectly) }\end{array}$ & None & $\begin{array}{l}\text { Country Counterparts; } \\
\text { Implement certain } \\
\text { activities }\end{array}$ \\
\hline $\begin{array}{l}\text { Other Ministry of Health } \\
\text { offices } \\
\text { (such as National Institute } \\
\text { of Health; General } \\
\text { Epidemiology bureau and } \\
\text { the National Health } \\
\text { Insurance) }\end{array}$ & $\begin{array}{l}- \text { Diagnosis } \\
- \text { Surveillance of the epidemic } \\
\text { - Monitoring and evaluation of activities (in part) } \\
\text { - Funding of treatment and care (National Health } \\
\text { Ins.) }\end{array}$ & $\begin{array}{l}\text { Primarily STI \& } \\
\text { HIV strategy }\end{array}$ & \begin{tabular}{|} 
Mainly delegated to the \\
HIV strategy though the \\
Minister of Health \\
alternates as the head of \\
CONAMUSA.
\end{tabular} & $\begin{array}{l}\text { No (except in } \\
\text { special cases, } \\
\text { e.g. studies) }\end{array}$ & None & Country counterparts \\
\hline
\end{tabular}




\begin{tabular}{|c|c|c|c|c|c|c|}
\hline • & $\begin{array}{c}\text { Main responsibilities in HIV/AIDS policies } \\
\text { and programmes }\end{array}$ & $\begin{array}{l}\text { Involvement } \\
\text { with other } \\
\text { actors }\end{array}$ & $\begin{array}{l}\text { Level of } \\
\text { participation in } \\
\text { CONAMUSA }\end{array}$ & $\begin{array}{l}\text { Received } \\
\text { money from } \\
\text { the Global } \\
\text { Fund }\end{array}$ & $\begin{array}{c}\text { Role } \\
\text { change } \\
\text { after Global } \\
\text { Fund entry }\end{array}$ & $\begin{array}{l}\text { Relationship with } \\
\text { Global Fund }\end{array}$ \\
\hline $\begin{array}{l}\text { Other } \\
\text { Ministries (such as the } \\
\text { Ministries of Education; } \\
\text { Foreign Affairs; Labour; } \\
\text { Tourism, Women; and } \\
\text { Social Affairs and Justice). }\end{array}$ & $\begin{array}{l}- \text { The ministry of education: participates in } \\
\text { activities related to the promotion of healthy } \\
\text { lifestyles in adolescents and young people } \\
\text { - The Armed and Police forces: contribute to the } \\
\text { prevention and control of HIV/AIDS among } \\
\text { their populations. } \\
\text {-Others have very limited participation. }\end{array}$ & $\begin{array}{l}\text { Primarily the } \\
\text { government, } \\
\text { NGOs \& CSOs, } \\
\text { as well as some } \\
\text { UN agencies. }\end{array}$ & Low/medium & $\begin{array}{l}\text { Yes (indirectly, } \\
\text { primarily: } \\
\text { education and } \\
\text { justice) }\end{array}$ & \begin{tabular}{|c|} 
Increased \\
involvement \\
in HIV \\
activities
\end{tabular} & $\begin{array}{l}\text { Country Counterparts; } \\
\text { Implement certain } \\
\text { activities }\end{array}$ \\
\hline \multicolumn{7}{|c|}{ Non-Governmental Organisations (NGOs) } \\
\hline $\begin{array}{l}\text { HIV/AIDS } \\
\text { service } \\
\text { organisations }\end{array}$ & $\begin{array}{l}\text {-Social advocacy to increase prevention and } \\
\text { access to treatment and care } \\
\text { - Main implementers for Global Fund projects }\end{array}$ & All sectors & High & Yes & \begin{tabular}{|c|} 
Switched \\
their role \\
from \\
advocacy to \\
project \\
implementati \\
on \\
\end{tabular} & $\begin{array}{l}\text { Principal and sub- } \\
\text { recipients of projects } \\
\text { (some) }\end{array}$ \\
\hline $\begin{array}{l}\text { PLHA } \\
\text { organisations }\end{array}$ & $\begin{array}{l}\text { - Support and training of their constituents } \\
\text { - Advocate for access to treatment and } \\
\text { improvement in care } \\
\text { - Implementation of activities }\end{array}$ & All sectors & High & Yes & \begin{tabular}{|} 
Switched \\
their role \\
from \\
advocacy to \\
project \\
implementati \\
on
\end{tabular} & $\begin{array}{l}\text { Subrecipients of } \\
\text { projects (some) }\end{array}$ \\
\hline
\end{tabular}




\begin{tabular}{|c|c|c|c|c|c|c|}
\hline - & $\begin{array}{c}\text { Main responsibilities in HIV/AIDS policies } \\
\text { and programmes }\end{array}$ & $\begin{array}{l}\text { Involvement } \\
\text { with other } \\
\text { actors }\end{array}$ & $\begin{array}{l}\text { Level of } \\
\text { participation in } \\
\text { CONAMUSA }\end{array}$ & $\begin{array}{l}\text { Received } \\
\text { money from } \\
\text { the Global } \\
\text { Fund }\end{array}$ & $\begin{array}{c}\text { Role } \\
\text { change } \\
\text { after Global } \\
\text { Fund entry }\end{array}$ & $\begin{array}{l}\text { Relationship with } \\
\text { Global Fund }\end{array}$ \\
\hline $\begin{array}{l}\text { LGBT, MSM, TS and sex } \\
\text { worker } \\
\text { organisations }\end{array}$ & $\begin{array}{l}\text {-Social advocacy } \\
\text { - Representing their peers at the policy-level } \\
\text { - Educating their peers } \\
\text { - Implementation of activities }\end{array}$ & All sectors & High & Yes & \begin{tabular}{|c|} 
Switched \\
their role \\
from \\
advocacy to \\
project \\
implementati \\
on \\
\end{tabular} & $\begin{array}{l}\text { Subrecipients of } \\
\text { projects (some) }\end{array}$ \\
\hline $\begin{array}{l}\begin{array}{l}\text { Faith-based } \\
\text { organisations }\end{array} \\
\text { oration }\end{array}$ & $\begin{array}{l}\text { - Primarily involved in the care of children and } \\
\text { women living with HIV/AIDS. }\end{array}$ & $\begin{array}{l}\text { State, other } \\
\text { NGOs and } \\
\text { PLHA }\end{array}$ & Low & Indirectly & \begin{tabular}{|c|} 
Increased \\
involvement \\
in HIV \\
activities \\
\end{tabular} & None \\
\hline $\begin{array}{l}\text { International NGOs (e.g. } \\
\text { CARE, Pathfinder, local } \\
\text { IPPF Affiliate) }\end{array}$ & $\begin{array}{l}\text {-Managing Global Fund projects } \\
\text { - Involved in implementation of activities }\end{array}$ & All sectors. & Low & Yes & \begin{tabular}{|c|} 
Increased \\
involvement \\
in HIV \\
activities
\end{tabular} & $\begin{array}{l}\text { Principal and sub- } \\
\text { recipients of projects }\end{array}$ \\
\hline $\begin{array}{l}\text { UN } \\
\text { agencies }\end{array}$ & $\begin{array}{l}\text {-Providing technical assistance } \\
\text { - Funding training and projects }\end{array}$ & All sectors & Low & No & $\begin{array}{l}\text { Decreased } \\
\text { funding }\end{array}$ & $\begin{array}{c}\text { Supports Global Fund } \\
\text { projects }\end{array}$ \\
\hline $\begin{array}{l}\text { Other } \\
\text { bilateral } \\
\text { organisations }\end{array}$ & $\begin{array}{l}\text {-Technical assistance } \\
\text { - Provision of funding to support government } \\
\text { projects and research. }\end{array}$ & $\begin{array}{l}\text { State, NGOs and } \\
\text { CSOs. }\end{array}$ & Low & No & $\begin{array}{l}\text { Decreased } \\
\text { funding }\end{array}$ & $\begin{array}{c}\text { Supports Global Fund } \\
\text { projects }\end{array}$ \\
\hline
\end{tabular}




\begin{tabular}{|l|l|l|c|c|c|}
\hline - & $\begin{array}{c}\text { Main responsibilities in HIV/AIDS policies } \\
\text { and programmes }\end{array}$ & $\begin{array}{c}\text { Involvement } \\
\text { with other } \\
\text { actors }\end{array}$ & $\begin{array}{c}\text { Level of } \\
\text { participation in } \\
\text { CONAMUSA }\end{array}$ & $\begin{array}{c}\text { Received } \\
\text { money from } \\
\text { the Global } \\
\text { Fund }\end{array}$ & $\begin{array}{c}\text { Role } \\
\text { change } \\
\text { after Global } \\
\text { Fund entry }\end{array}$ \\
$\begin{array}{c}\text { Relationship with } \\
\text { Global Fund }\end{array}$ \\
\hline Academia & $\begin{array}{l}\text { - Conducting research } \\
\text { - Capacity building } \\
\text { - Contributing to the development of policy } \\
\text {-Serving as external reviewers for Global Fund } \\
\text { projects. }\end{array}$ & $\begin{array}{l}\text { All other sectors } \\
\text { directly or } \\
\text { indirectly. }\end{array}$ & Low & $\begin{array}{c}\text { Occasionally } \\
\text { (activity-based) }\end{array}$ & $\begin{array}{c}\text { None } \\
\text { pxojects; occasionally as } \\
\text { consultants }\end{array}$ \\
\hline
\end{tabular}




\section{Actor incentives}

\section{The Non-Governmental Organisation (NGO) dilemma}

NGOs emerged as important actors due to their strong CONAMUSA representation and important role as programme implementers, especially in HIV prevention. The Global Fund funding led to the emergence of many new NGOs together with older ones, which was seen (both by donor and NGOs representatives) as a positive development since it might contribute, in theory, to a more effective way of reaching vulnerable groups, strengthened the political position of these groups, and increased their training and overall capacity. However, respondents from other sectors argued that the role of NGOs primarily as project executers hindered the NGOs' ability to advocate for their constituents and make the government accountable to agreements made due NGOs' commitment to producing results. NGOs' ability to assure government accountability was identified as a key element to guarantee that successful Global Fund-funded activities would be continued.

“...People Living with HIV/AIDS' organisations should return to what they should have never left, their role of social oversight... from the moment they became involved as project executers, I think they lost this role (Academia respondent)."

Moreover, the pattern of direct funding has also diminished the steering and coordinating role of the Ministry of Health, with a government official stating that Global Fund NGO subrecipients frequently made unilateral decisions without consulting government bodies.

On the one hand, NGO leaders reported that they are organised into networks to coordinate their work towards common goals, such as demanding greater access to medications. However, on the other hand, a concern voiced by members of academia was that NGO 
involvement in these networks is on an adjunct basis, meaning they are not held accountable. A more important side effect has been that isolated and uncoordinated programmes led by NGOs resulted in insufficient political activism to ensure access to HIV services for all. This lack of coordination with the HIV strategy office was seen as a hindrance to a coherent response to HIV/AIDS, as well as a detrimental for the constituents these NGOs represent.

\section{Effective coordination yet dwindling commitments}

Central to the continuity of activities is the ability and commitment of the different actors to work together in a coordinated and coherent manner towards common goals. It is a widely supported view that the CONAMUSA since its constitution in 2004 has been instrumental in bringing together the main actors working with HIV and developing proposals.

"When people meet each other and develop trust, they work better together; I think this is what the Global Fund has been able to do (NGO respondent)."

However, a frequent criticism both from national and regional actors is that decision-making has been concentrated at the national level, with little input from regional leaders, as well as the lack of active involvement of other ministries besides the Ministry of Health. Thus, many respondents from the NGO sector stated that there is no real 'multisectoral' response. This multisectoral response was an important factor for all of the actors, since it meant HIV/AIDS would be seen as a national policy priority, and not only one for the health sector. This would in their view, ensure that the HIV/AIDS response would continue to receive funding in the long-term. Moreover, some respondents with health systems expertise viewed the preparation of proposals to the Global Fund as insufficiently reflective of population need but corresponding to the interests of the principal recipient or the organisations that participated in the CONAMUSA assembly. 
As stated by the majority of the respondents, the work of the COREMUSAs (regional coordinating bodies) has varied in terms of performance mostly due to overburdened staff and lack of resources. However, Callao, one of the regions most strongly affected by HIV, was frequently noted by sub-national respondents, as an example of success mainly due to their multisectoral efforts convened through their regional committee. This was explained as resulting from committed individuals who met regularly and understood the needs in the region. In addition, round six of the Global Fund was seen among NGO leaders as bringing a different way of working, from implementing projects in the regions directed from the central-level, to developing macro-region (groupings of regions) led projects so local capacities could be strengthened; this was seen as a positive legacy of inter-regional work.

In comparison, a common perception of respondents about the relationship between the stakeholders in the long-term was that a lack of commitment for collaborative work: "There is a divorce between the State and the organisations to intervene. When it does happen it is because the funders force them to or it is part of the requirements for funding but it is not because the State wants to work closely with NGOs (NGO respondent)".

Indeed, respondents at all levels saw the rules for receiving a Global Fund grant to be fostering better accountability and collaborative work across sectors and requiring political will at the government level by promoting HIV as a priority. In this sense, NGO respondents saw the Global Fund proposal process as laying the ground for stronger political commitment. This point of view was shared by several government respondents, which reported that their actions are driven not only by the need to continue the response to HIV, but also to take a formal responsibility to sustain the commitments expressed in their grant proposals. 


\section{Programme implementation}

The changes in actor incentives and behaviour have had a direct impact on programme implementation, both in terms of strategies and policies for HIV/AIDS and the effects of the sociopolitical decentralisation. This has been a gradual process, with complete transfer of health functions to the regions concluding in 2008 .

\section{HIV/AIDS: a national priority but with a weak strategy}

Themes around planning and strategy emerged as key in the analysis of the potential for sustainability. Central to effective programming is the ability to develop and enact a strategy reflecting national priorities including the priority of HIV/AIDS in the country. All respondents agreed that a single national HIV strategy is the best approach to integrate the health, education, development and law enforcement sectors working in this area thereby building the foundations for lasting and effective actions: "The Multisectoral Strategic Plan has undoubtedly been an important tool for planning, but in this new government we need to build on this knowledge and motivation of the government to develop a new multisectoral plan (NGO respondent)."

However, the development of this strategy has not been easy. Respondents recalled that following a first frustrated attempt for the 2001-2003 period, the 2007-2011 Multisectoral Strategic Plan for the Prevention and Control of STIs and HIV/AIDS was approved. This strategic planned signalled a concerted effort from different sectors would be needed to increase HIV/AIDS treatment and prevention under the leadership of the Ministry of Health (Ministerio de Salud del Peru, 2006). The shared opinion with regards to this plan was that the participation of the various actors in its development meant they were invested in working within this framework. Yet a view from the NGO sector was that the plan objectives were too ambitious both in terms of results and funding required within this time period; as 
well as having weak prevention strategies, especially among the most vulnerable populations including MSM and transgender women.

Though at the time of the interviews in 2011 the appointment of the President was fairly recent, the predominant view among the respondents as compared to prior more conservative administrations, was that HIV was perceived as being of a higher priority for the central government than before and was expected to continue as such. This was supported with the fact that the government the included HIV/AIDS, together with TB, as a national health strategic line of the results-based budgetary strategy in 2011. This meant that HIV/AIDS programmes were given a separate budget instead of being aggregated within the general health budget, as was previously the case.

As stated by NGO leaders, although a limited number of regions have developed Regional Multisectoral Strategic Plans for HIV/AIDS, where they do exist, they are seen as more successful than the National Multisectoral Strategic Plan for STI and HIV/AIDS due to the smaller number of actors involved.

An issue negatively affecting the sustainability of actions and progress in the response was the lack of a national strategic plan for 2012-2016, which is yet to be approved. This was frequently seen as a major concern since it essentially implied that the different sectors involved continue to work under guidelines and indicators set over six years ago.

\section{Global Fund as a facilitator for new models of working}

The process of applying for and implementing Global Fund grants emerged as important preparation for setting long-term sustainable policies. The Global Fund proposals both affected and were affected by national planning processes. The development of the round six 
Global Fund grant in line with the objectives of the multisectoral plan was considered as key by the majority of the respondents, and this was seen as a measure of significant progress in aligning donor activities with national policy. Furthermore, although one of the objectives within the plan was to strengthen the monitoring and evaluation mechanisms to follow up on the results of the plan itself, the lack of updated and quality data remains a major concern among all of the sectors interviewed, especially within academia.

Additionally, two of the most common views among respondents of the influence of the Global Fund in long-term planning are: (1) in requiring the creation of the CONAMUSA, which has become the main multisectoral policy space to discuss HIV issues; and (2) in serving as a catalyst to implement new strategies. In this sense, it was seen as a useful mechanism to begin to pilot or expand strategies proposed by the Ministry of Health and also an opportunity to study the cost-effectiveness of certain activities; with one respondent stating that international cooperation has the tools to operationalise plans faster and in a more effective manner than the government itself: "There are things that operationally the international cooperation can do faster, in a more effective and efficient manner than the State itself (NGO respondent).”

The most commonly cited example by respondents of the piloting of strategies was the first phase of the Global Fund's round two grant in 2004 which was identified at that moment as an important driver for implementing health promotion activities and most importantly, increasing access to ART. By 2006, the provision of free ART was fully funded by the government; which had a positive effect on coverage and was seen to mark a first step towards sustaining the results of the Global Fund programmes. Yet this is somewhat contested by respondents from NGOs who expressed concerns that the distribution of ART often does not reach the most vulnerable populations, and the issues are compounded by the lengthy tender of the medications frequently resulting in disrupted supply. 
Round 10 (approved in 2011) was seen as an important success for the NGOs since it was specifically formulated to increase access to services and decrease stigma and discrimination among MSM and transwomen; again placing greater attention on addressing this issue at the national level.

\section{Rapid decentralisation hampering leadership and governance}

The governance capacity in Peru is an essential component of ensuring continuity of successful HIV programmes. The process of decentralisation emerged as having a large effect on the central-level leadership in HIV. It was a predominant view that decentralisation took place rapidly, with insufficient preparation and without verifying capacities of different actors to act, given the transfer of responsibilities from central to regional level.

"There are still difficulties in the management capacity, which means that even though the resources are available, they may not all be planned for or implemented at the regional level (Academia respondent)."

Meanwhile, at the central level, the STI and HIV programme in the Ministry of Health was transformed in 2004 into an STI and HIV strategy office. According to government officials, this resulted to major change in responsibilities. The head of the HIV programme who was previously director of the programme became a facilitator of HIV activities within what is now deemed a 'strategy' department.

According to some respondents, though this strategy office should coordinate the work around HIV in the country, in practice its position has at times been limited. A key source of this, identified in interviews with those working outside the government, was the technical 
capacity of the strategy team which was seen as smaller compared to the one found in other larger organisations. According to academia and NGO actors, this weakness has been compounded by the significant number of personnel within the strategy team hired with Global Fund money. This was confirmed by several government officials who reported that, in 2005 there were officially three people hired by the Ministry of Health and 10 more people hired with Global Fund support. Up until the moment the interviews were being conducted, several of those 10 people were still being funded by the Global Fund, though they were seeking to be incorporated into the regular Ministry of Health budget. Nonetheless, while certain procedures such as the purchase of ART still take place at the central level; within the present context of decentralisation, it is the regions who develop the plans and budgets.

The prior experience with the Global Fund, which is also based on indicators and results, was expressed by members of the CONAMUSA as an important strength in transitioning to results-based budget. However, the tension between planning and managing, and how the funding was implemented in the regions were evident from the beginning. It was suggested this was primarily in terms of poorly developed plans given the budgets available; not allocating all of the funding available or deviating funds for other purposes; and also what some deemed 'cultural and political' motivations.

"We have had to travel to the regions to explain that the results-based budget is to reach targets; that they can diversify a little, taking advantage of this push to fix other things that aren't working, but first they have to reach the goals... this has been an important challenge, explaining to these people who are used to the immediate political moment, the world of political campaigning, who [think that] if everything is ok right now, tomorrow is not as important (Government respondent) ". 
Four areas emerged among the respondents in government, academia and NGOs as the most important causes for this poor execution of budget plans for HIV activities. These were that the plan was prematurely rolled-out without proper planning, monitoring mechanisms and lack of training, which led to inappropriate identification of needs and funding requirements; with short timelines. In one instance, a region had to develop the budget in four days, with very little dialogue between the central, regional-level and local levels, and with no access to up to date data on health indicators and human resources distribution, to inform planning. This lack of quality data also had an important effect on accountability, with respondents from academia and NGOs noting that this hampers tracking and corroborating results.

\section{Looking towards the future: perceived contribution to sustainable programming}

The perception of the actors on what sustainability entailed and their contribution to it demonstrates both their vision for the future and what they consider priority areas that need to be addressed for a sustained HIV response. It is a widely shared view that although the basic prevention activities and universal treatment would continue, there is also a need to maintain other successful prevention activities such as NGO-managed peer-promoters for health promotion and micro-finance projects, an activity the other sectors disagreed with, seeing it as a failed project; as well as ensuring the political will to continue to see HIV/AIDS as a priority issue in the long-term, also linked to the financial resources from the government. The need to enhance country governance and capacity was also a concern among respondents in various sectors, given the issues in the initial years of the results-based budget.

Furthermore, a common thread throughout all of the interviews was that for sustainable planning, there was a need for greater advocacy and accountability of government activities on behalf of NGOs; a role which until that moment was perceived as weakened. One 
respondent went as far as suggesting that NGOs had to transition from a focus on their constituents to support a shared goal of increasing access to the population in general.

Yet when asked about their future role post-Global Fund environment, most stakeholders believed their roles would not change. The NGO respondents were divided in their opinion, with some stating they would continue their advocacy work, albeit with less resources; while the majority were concerned about the uncertainty of how to continue their activities and supporting the need for a continued research and peer-promoter projects among their constituents. At that time they had not been approached by the Ministry of Health in participating in the results-based budget, though they expressed the interest in continuing their role as project implementers.

The role of CONAMUSA as a space to convene different actors would end with the exit of the Global Fund, according to actors belonging to sectors outside of the government; unless efforts are made to reconfigure its mandate or a separate mechanism is created. Although some government respondents saw the CONAMUSA as a valuable mechanism, they suggested that in the long-term it will no longer be necessary, given that the regions would take over the majority of planning and NGOs would cease implementing projects. Even so, many other believed the COREMUSAs which in some regions have gained political support and have a more operational role, would likely continue to exist.

\section{Discussion}

This paper sought to examine the process of promoting sustainability of HIV programmes following the exit of a major donor, the Global Fund. This issue has received surprisingly little attention in the literature despite its relevance to multiple settings. The roles and 
behaviours of the main country stakeholders were analysed during the transition of Global Fund entry in 2004, with subsequent implementation of four grants, and then the increased role of national institutions in 2012, associated with the scaling down of the Global Fund involvement and how they impact and promote the sustainability of the HIV response.

Certain limitations have to be acknowledged. Some recall bias of the respondents may have occurred, given that they were asked about the history of current initiatives and policies; however, there was an effort to signpost and remind the respondents about the basic timeline of events. Inevitably, the personal interests and position of the respondents may have influenced their responses, however, this was offset by interviewing a wide-range of respondents and using triangulation to cross-examine findings. The study employed a case study methodology tailored to the unique characteristics of the country, nonetheless there is a level of conceptual generalizability and identifying lessons that are relevant to other countries in terms of useful structures and mechanisms for sustainability.

According to the definition for sustainability employed in this study, namely the ability of the government to manage health programmes long-term without depending on the intervention of external bodies for technical or financial support; our findings demonstrate that Peru has made significant steps towards sustainability of the HIV/AIDS response. The creation of partnerships and early alignment of Global Fund activities with national policies were found to be enabling factors for sustainability. Moreover, the use of the CONAMUSA and the decentralised COREMUSAs as spaces for intersectoral discussion, suggests that these working relationships can carry on in the long-term. Furthermore, the inclusion of HIV/AIDS in the results-based budget and the transfer of the responsibilities to the regions, demonstrates that the country is focused on improving the performance of their HIV programme and increasing access to care by maintaining some of the previous activities. A sustainable HIV/AIDS response in Peru is highly dependent on policies ensuring the continuity of 
successful activities. The literature shows that aligning donor activities with government policies promotes a sustainable and coherent national response (Bossert, 1990; Hay \& Williams, 2005; Johnson, Hays, Center \& Daley, 2004; OECD, 2008; OECD, 2011; Scheirer, 2005; Tibbitts et al., 2010). Furthermore, the existence of an alignment plan among different actors demonstrates that there is a demand for these activities and facilitates the institution building and strategies required by phasing-out of funding (Slob \& Jerve, 2008). Peru started the process of aligning Global Fund activities with local priorities early on. This ensured that activities were integrated within the national response; although, our findings also show that prevention activities implemented by NGOs were still being prioritised.

On the other hand, the literature also shows that effective partnerships among country stakeholders is an important element of a coherent strategy and coordinated response (Johnson, Hays, Center \& Daley, 2004; Scheirer, 2005), as well as their ability to hold members accountable (Walsh, Mulambia, Brugha \& Hanefeld, 2012). Peru has made important progress in this area. The wide representation of actors in the CONAMUSA and their use as the main policy spaces for inter-sectoral dialogue on HIV issues are an important legacy of the Global Fund in the country. Despite relatively weak coordination by the HIV strategy office, these partnerships have flourished due to positive personal working relationships between actors. The use of the CONAMUSA to discuss the 2007-2011 Multisectoral Strategic Plan for the Prevention and Control of STIs and HIV/AIDS demonstrates that the CONAMUSA's contribution to policy goes beyond developing proposals for the Global Fund.

However, if these gains are to be sustained, the coordinating mechanisms will have to be promoted and strengthened and an increased focus on improving the capacities at the Ministry of Health and regional-level, is essential. Other major limiting factors to this sustainability are posed by the predominant role of NGOs in implementing prevention 
activities, at times threatening a coherent response and the still weak accountability role of NGOs as overseer of government commitments.

Consequently, in 2004-2012, the nature of the Global Fund funding in Peru has changed dramatically, with increasing participation of the government in financing the HIV programme (Ministerio de Salud del Peru, 2012). This has occurred amidst a decentralisation process and a problematic process of planning and implementing the results-based budget in the regions, pointing to the need to train the health professionals in the regions on these changes. This need for strengthening local health capacity following decentralisation is not unique to Peru. Brazil and Russia, large federal states, have faced similar challenges during their process of decentralisation primarily in ensuring role clarity (Collins, Araujo \& Barbosa, 2000) and effective decision-making (Danishevski, Balabanova, McKee \& Atkinson, 2006), though in the Russian case decision-making power is associated with historical political ties and a complex hierarchical system.

Unlike other countries such as Ghana (Atun \& Kwansah, 2011) and Mozambique (Ooms, Van Damme \& Tammermann, 2007), Peru does not require Global Fund financing to expand their ART program given that the government has fully financed ART provision since 2006. However, in Peru the Global Fund has financed most HIV prevention efforts, similar to Kazakhstan (UNAIDS, 2013) and Kenya, where the majority of health promotion activities are donor funded and implemented by NGOs (Wamani, 2004). Moreover, though the basic prevention activities are included in the results-based budgets there is still uncertainty about the targeted prevention work focused on vulnerable populations, particularly since there is no national precedent of contracting NGOs to deliver services paid by public budgets. Some of the problems that emerge have parallels in India, experiencing rapid economical growth and involving NGOs in project implementation (Chakma, 2013) but facing challenges in ensuring 
efficient monitoring mechanisms and accountability structures to ensure that public grants are reaching the most vulnerable populations.

Indeed, Peru is unique in many ways due to the ongoing process of decentralisation and increased economic growth, yet there are a number of patterns that emerge and can inform other settings. The difficulty in reaching vulnerable populations is relevant for other countries, particularly those that are also experiencing economic growth given that this growth has frequently been associated with increased social and economic inequality (Kuznets, 1955; Morrison, 1999). This is concerning for stakeholders working in the HIV/AIDS field given the rise in prevalence in many countries among traditionally sociallyexcluded groups; making it crucial to consider the effects of both economic and social inequality on the HIV/AIDS response and generate strategies to address these effects.

Additionally, the predominant role of NGOs in Peru in prevention programmes at times making unilateral decisions, threatened a coherent programme response and undermined the coordinating role of the Ministry of Health-based HIV strategy office. Similar governance issues as a result of new partnership models has been found in multiple settings (Caines et al., 2004; Kapilashrami \& McPake, 2013; Ooman, Bernstein \& Rosenzweig, 2008; Spicer et al., 2010; WHOMPS, 2009). An example of this is found in Zambia where PEPFAR's support of civil society was observed to be at the cost of building government capacity (Ooman, Bernstein \& Rosenzweig, 2008). Moreover, the literature shows that this focus of NGOs on project implementation may have negative effects on the vulnerable populations these organisations are meant to serve; which in their work with international bodies, refocus their agendas on short-term interventions (Kapilashrami \& O’Brien, 2012; Seckinelgin, 2005), also resulting in a loss of legitimacy of their original role (Doyle \& Patel, 2008; Kapilsashrami \& O’Brien, 2012; Spicer et al., 2011). 
However, the transitional period where Global Fund support was phased out also presents an opportunity for NGOs to retake this social accountability role. Similar to the agreements signed at CONAMUSA to remain independent of decision-making when applying for funding (Ministerio de Salud del Peru, 2006), NGOs should also commit to being accountable themselves in the long-term, via self-regulation with a supporting enforcement structure either at the sectoral or national level, or through independent assessments (Lloyd, 2005). However, this study clearly demonstrates that the role of the HIV/AIDS strategy

office - through its central coordinating, oversight and advisory role in relation to the regions - is key in ensuring sustainable HIV policy and programmes.

\section{Conclusion}

The study findings demonstrate some of the enabling and limiting factors for sustainability of the HIV/AIDS response in Peru. Important enabling factors identified for sustainability of the HIV/AIDS programme in the country have been the creation of spaces for intersectoral work; early alignment of grant activities with local policies; focus on most-at-risk populations; and (in theory) universal access to treatment. The inclusion of HIV/AIDS activities into the new budgetary strategy based on results also points to increased political willingness to allocate an appropriate budget to address the HIV/AIDS epidemic according to need. However, factors limiting the sustainability of the response were found to be associated with poor technical capacity at the central and regional level; the weakened social advocacy and accountability role of all actors; and the threat posed by a predominant role of NGOs in prevention activities to a coherent HIV/AIDS response.

Addressing the weaknesses in the HIV strategy office will not only support the overall response to HIV/AIDS by improving the coordination of activities and the provision of 
guidance for the regions but will also result in generating more productive and effective partnerships. This requires both investing in training policy-makers on managerial and technical skills, as well as increasing their budget so they have the resources necessary to respond to the demanding task of liaising with 25 regions. Increasing the advocacy and social accountability role of the NGOs and CSOs is critical to ensure government commitments are maintained and HIV/AIDS continues to be a political priority, according to needs.

Moreover, as our findings demonstrate that sustainability, is not only about continuing prior activities but also evolving strategies which respond to new evidence, resources and need. The changes brought by economic growth and increased social inequality, which can result in greater difficulty reaching most-at-risk populations, is an example of possible future challenges that the government will need to tackle. However, this will only be successful if the foundations for sustainability are in place; the nine-year presence of the Global Fund has catalysed some of these processes, but it is now the responsibility of the country actors to sustain and build on these gains. 


\section{References}

Atun, R., McKee, M., Drobniewski, F. \& Coker, R. (2005). Analysis of how the health systems context shapes responses to the control of human immunodeficiency virus: case studies from the Russian Federation. Bulletin of the World Health Organization, 83, 730-738.

Atun, R.\& Kwansah, J. (2011). Critical interactions between the Global Fund-supported HIV programs and the health system in Ghana. Journal of Acquired Immune Deficiency Syndrome, 57, S72-S76.

Bossert, T. J. (1990). Can they get along without us? Sustainability of donor-supported health projects in Central America and Africa. Social Sciences of Medicine, 30, 1015-1023.

Bracht, N., Finnegan, J. R., Rissel, C., Weisbrod, R., Gleason, J., Corbett, J., Veblen-Mortenson, S. (1994). Community ownership and program continuation following a health demonstration project. Health Education Research, 9, 243-255.

Buffardi, A., Cabello, R.\& Garcia, P. (2011, March). The chronicles of CONAMUSA: Institutional strategies to overcome shared governance challenges. Paper presented at the Annual Convention of the International Studies Association, Montreal.

Cabrera, A. (2010). Propuesta de alineamiento de los planes de sostenbilidad y transferencia de los objetivos del programa de la ronda 6 con el presupuesto por resultados del programa estrategico de prevencion y control del VIH y SIDA y otros instrumentos del marco rector nacional. Lima: ONUSIDA.

Caceres, C., Giron, M., Sandoval, C., Lopez, R., Pajuelo, J., Valverde, R. et al. (2009). Effects of the implementation of Global Fund-supported HIV/AIDS projects on health systems, civil society and affected communities, 2004-2007. In The Maximizing Positive Synergies Academic Consortium (Ed.), Interactions between Global Health Initiatives and Health Systems: evidence from countries (pp. 134-143). Geneva: World Health Organization.

Caines, K., Buse, K., Carlson, C. et al. (2004). Assessing the impact of Global Health Partnerships. London: DFID Health Resource Centre.

Chakma, S. (2013). India's funds to NGOs squandered. New Delhi: Asian Centre for Human Rights.

Collins, C., Araujo, J.\& Barbosa, J. (2000). Decentralising the health sector: Issues in Brazil. Health Policy, 52, $113-127$

Danishevski, K., Balabanova, D., McKee, M.\& Atkinson, S. (2006). The fragmentary federation: experiences with the decentralized health system in Russia. Health Policy and Planning, 21, 183-194.

Dickinson, C. (2008). Global health initiatives and health system strengthening: the challenges of providing technical support. London: HLSP Institute.

Doyle, C., Patel, P. (2008). Civil society organizations and global health initiatives: Problems of legitimacy. Social Science and Medicine, 66, 1928-1938.

Glassman, A., Duran, D.\& Sumner, A. (2012). Global health and the new bottom billion: what do shifts in global poverty and disease burden mean for donor agencies? Global Policy, 4, 1-14.

Global Fund to fight AIDS, Tuberculosis and Malaria. (2012). Peru - Grant portfolio. Retrieved from http://portfolio.theglobalfund.org/en/Grant/List/PER

Global Fund to fight AIDS, Tuberculosis and Malaria (2011a). Policy on eligibility criteria, counterpart financing requirements, and prioritization of proposals for funding from the Global Fund. Geneva: The Global Fund to Fight AIDS, Tuberculosis and Malaria.

Global Fund to fight AIDS, Tuberculosis and Malaria (2011b). Guidelines and requirements for country coordinating mechanisms. Retrieved from http://www.theglobalfund.org/en/ccm/guidelines/ 
Global Fund to fight AIDS, Tuberculosis and Malaria. (2011c). The Global Fund Strategy 2012-2016: Investing for Impact. Geneva: The Global Fund to fight AIDS, Tuberculosis and Malaria.

Global Fund to fight AIDS, Tuberculosis and Malaria. (2009). Global Fund to provide \$24 million of new funding to fight HIV/AIDS in Russia [Press release]. Retrieved from http://www.theglobalfund.org/en/mediacenter/newsreleases/2009-1113_Global_Fund_to_provide_USD_24_million_of_new_funding_to_fight_HIV_AIDS_in_Russia/

Green, J. \& Thorogood, N. (2004). Qualitative methods for health research. London: Sage Publications Ltd.

Gruen, R., Elliot, J., Nolan, M., Lawton, P., Parkhill, A., McLaren, C. \& Lavis, J. (2008). Sustainability science: an integrated approach for health-programme planning. The Lancet, 372, 1579-1589.

Hay, R. \& Williams, G. (2005). Fiscal space and sustainability from the perspective of the health sector. In: High-level forum on the health Millennium Development Goals: selected papers 2003-2005 (pp. 44-66). Geneva: World Health Organization.

International AIDS Society. (2009). Global Fund extension of HIV prevention programmes for people at high risk for HIV in Russia will save thousands of young lives [Press release]. Retrieved from http://www.iasociety.org/Default.aspx?pageId=383

Johnson, K., Hays, C., Center, H. \& Daley, C. (2004). Building capacity and sustainable prevention innovations: a sustainability planning model. Evaluation and Program Planning, 27, 135-149.

Kapilashrami, A. \& O'Brien, O. (2012). The Global Fund and the re-configuration and re-emergence of 'civil society': widening or closing the democratic deficit? Global Public Health, 7, 437-451.

Kapilashrami, A. \& McPake, B. (2013). Transforming governance or reinforcing hierarchies and competition: examining the public and hidden transcripts of the Global Fund and HIV in India. Health Policy and Planning, 28, 626-635.

Kuznets, S. (1955). Economic growth and income inequality. American Economic Review, 65, 1-28.

LaPelle, N., Zapka, J. \& Ockene, J. (2006). Sustainability of public health programs: the example of tobacco treatment services in Massachusetts. American Journal of Public Health, 96, 1363-1369.

Lele, U., Sarna, N., Govindaraj, R.\& Konstantopoulos, Y. (2004). Global Health programs, Millennium Development Goals and the World Bank's role. Addressing challenges of globalization: An independent evaluation of the World Bank's approach to global programs. Washington, D.C.: World Bank.

Lloyd, R. (2005). The role of NGO self-regulation in increasing stakeholder accountability. London: One World Trust.

Lu, C., Michaud, C., Khan, K.\& Murray, C. (2006). Absorptive capacity and disbursements by the Global Fund to fight AIDS, Tuberculosis and Malaria: analysis of grant implementation. The Lancet, 368, 483-488.

Mays, N. \& Pope C. (2000). Qualitative research in health care: assessing quality in qualitative research. British Medical Journal, 320, 50-52.

Ministerio de Economia y Finanzas del Peru. (2012). Consulta Amigable: consulta de ejecucion del gasto [Data set]. Retrieved from: http://ofi.mef.gob.pe/transparencia/Navegador/default.aspx?y=2011\&ap=ActProy

Ministerio de Salud del Peru. (2006). Plan estrategico multisectorial para la prevencion y control de las ITS y el VIH/SIDA en el Peru (2007-2011). Lima: Ministerio de Salud del Peru.

Ministerio de Salud del Peru (2012). Informe nacional sobre los progresos realizados en el pais. Lima: Ministerio de Salud del Peru.

Morrison, C. (2000). Historical perspectives on income distribution: the case of Europe. In: A. B. Atkinson \& F. Bourguignon (Eds.), Handbook of income distribution (pp. 220-259). Amsterdam: North-Holland. 
Navarro de Acosta, M. (2011). Medicion del gasto en SIDA - MEGAS. Lima: Ministerio de Salud.

OECD (Organisation for Economic Cooperation and Development). (2008). Paris Declaration and Accra Plan of Action. Paris: OECD.

OECD (Organisation for Economic Cooperation and Development). (2011). Busan partnership for effective development co-operation. Retrieved from: http://www.oecd.org/dac/effectiveness/49650173.pdf

Olsen, I. (1998). Sustainability of health care: a framework for analysis. Health policy and planning, 13, $287-$ 295.

Oomman, N., Bernstein, M. \& Rosenzweig, S. (2008). The numbers behind the stories. Washington D.C: Center for Global Development.

Ooms, G. (2006). Health development versus medical relief: the illusion versus the irrelevance of sustainability. PloS Medicine, 3, e345.

Ooms, G., Van Damme, W. \& Temmermann, M. (2007). Medicines without doctors: why the Global Fund must fund salaries of health workers to expand AIDS treatment. PloS Medicine, 4, e128.

Ostrom, E., Gibson, C., Shivakumar, S. \& Andersson, K. (2001). Aid, incentives and sustainability: an institutional analysis do development cooperation. Stockholm: SIDA.

Pluye, P., Potvin, L. \& Denis, J. L. (2004). Making public health programs last: conceptualizing sustainability. Evaluation and Program Planning, 27, 121-133.

Scheirer, M. A. (2005). Is sustainability possible? a review and commentary on empirical studies of program sustainability. American Journal of Evaluation, 26, 320-347.

Schell, S., Luke, D., Schooley, M., Elliot, M., Herbers, S., Mueller, N. \& Bunger, A. (2013). Public health program capacity for sustainability: a new framework: Implementation Science, 8, 15.

Seckinelgin, H. (2005). Time to stop and think: HIV/AIDS, global civil society, and people's politics. In Anheir H, Glasius M, Calder M, eds. Global Civil Society. Oxford: Oxford University Press.

Shediac-Rizkallah, M.\& Bone, L. (1998). Planning for sustainability of community-based health programs: conceptual frameworks and future directions for research, practice and policy. Health Education Research, 13, 87-108.

Slob, A. \& Jerve, A. M. (2008). Managing aid exit and transformation: lessons from Botswana, Eritrea, India, Malawi and South Africa: synthesis report. Joint donor evaluation. Stockholm: Sida.

Spicer, N., Aleshkina, J., Biesma, R., Brugha, R., Caceres, C., Chilundo, B. et al. (2010). National and subnational HIV/AIDS coordination: are global health initiatives closing the gap between intent and practice? Globalization and Health, 6, 3.

Spicer, N., Harmer, A., Aleshkina, J., Bogdan, D., Chkhatarashvili, K., Murzalieva, G. et al.. (2011). Circus monkeys or change agents? Civil society advocacy for HIV/AIDS in adverse policy environments. Social Science and Medicine, 73, 1748-1755.

Stefanini, A. \& Ruck, N. (1992). Managing externally assisted health projects for sustainability - a framework for assessment. Leeds: University of Leeds.

Tibbits, M. K., Bumbarger, B. K., Kyler, S. J. \& Perkins, D. F. (2010). Sustaining evidence-based interventions under real-world conditions: results from a large-scale difussion project. Prevention Science, 11, 252-262.

Torpey, K., Mwenda L., Thompson, C., Wamuwi, E. \& van Damme, W. (2010). From project aid to sustainable HIV services: a case study from Zambia. Journal of the International AIDS Society, 13, 19. 
Twigg, J. (2007). HIV/AIDS in Russia: commitment, resources, momentum, challenges. Washington D.C: Centre for Strategic and International Studies.

UNAIDS (Joint United Nations Programme on HIV/AIDS).(2013). Efficient and sustainable HIV responses: case studies on country progress. Geneva: UNAIDS.

UNICEF (United Nations Children's Fund). (1992). Health policies and strategies, sustainability, integration and national capacity-building. New York: UNICEF.

Walsh, A., Mulambia, C., Brugha, R. \& Hanefeld, J. (2012). "The problem is ours, it is not CRAIDS"”. Evaluating sustainability of Community Based Organisations for HIV/AIDS in a rural district in Zambia. Globalization and Health, 8, 40 .

Wamani, R. (2004, July). NGO and public health systems: comparative trends in transforming health systems in Kenya and Finland. Paper presented at the International Society for third sector research, Toronto.

WHOMPS (World Health Organization Maximizing Positive Synergies Collaborative Group). (2009). An assessment of interactions between global health initiatives and country health systems. The Lancet, 373, 213769

World Bank (2013a). Country and lending groups. Retrieved from http://data.worldbank.org/about/countryclassifications/country-and-lending-groups\#Upper_middle_income

World Bank (2013 b). Data: GINI index. Retrieved from http://data.worldbank.org/indicator/SI.POV.GINI

Yin, R. (2003). Case study research: design and methods. Thousand Oaks: SAGE Publications Inc. 